\title{
Assessment of phytochemical content, polyphenolic composition, antioxidant and antibacterial activities of Leguminosae medicinal plants in Peninsular Malaysia
}

\author{
Yik Ling Chew', Elaine Wan Ling Chan¹, Pei Ling Tan', Yau Yan Lim¹, Johnson Stanslas², , Joo Kheng Goh ${ }^{1 *}$
}

\begin{abstract}
Background: Many medicinal plants from Leguminosae family can be found easily in Malaysia. These plants have been used as traditional medicines by local ethnic groups, where they are prepared as decoction, pastes for wound infections, and some have been eaten as salad. This paper focused on the assessment of antioxidant potential, antibacterial activity and classes of phytochemicals of nine plants from the Leguminosae family.

Methods: Acacia auriculiformis, Bauhinia kockiana, Bauhinia purpurea, Caesalpinia pulcherrima, Calliandra tergemina, Cassia surattensis, Leucaena leucocephala, Peltophorum pterocarpum, and Samanea saman were extracted with aqueous methanol and dichloromethane:methanol mixture to test for antioxidant and antibacterial activities. The Folin-Ciocalteu assay was conducted to quantify the total phenolic content and 2, 2-diphenyl-1-picrylhydrazyl (DPPH) assay was used to determine the free radical quenching capacity. Antibacterial activity was assessed using disc diffusion (Kirby-Bauer) assay. Screening for major classes of phytochemical was done using standard chemical tests.
\end{abstract}

Results: B. kockiana flowers and C. pulcherrima leaves contained high total phenolic content (TPC) and strong DPPH radical scavenging ability with TPC of $8280 \pm 498 \mathrm{mg} \mathrm{GAE} / 100 \mathrm{~g}, \mathrm{IC}_{50}$ of $27.0 \pm 5.0 \mu \mathrm{g} / \mathrm{mL}$ and TPC of $5030 \pm 602 \mathrm{mg}$ GAE/100 g, IC 50 of $50.0 \pm 5.0 \mu \mathrm{g} / \mathrm{mL}$ respectively. Positive correlation was observed between TPC and free radical scavenging ability. Most extracts showed antibacterial activity against Gram positive bacteria at $1 \mathrm{mg}$, while none showed activity against Gram negative bacteria at the same dose. All extracts (except Samanea saman flower) showed antibacterial activity against two strains of methicillin resistant Staphylococcus aureus (MRSA) with MID values ranging between $100 \mu \mathrm{g} / \mathrm{disc}$ and $500 \mu \mathrm{g} / \mathrm{disc}$.

Conclusion: The potential source of antioxidant and antibacterial agents, especially for MRSA infection treatments were found in B. kockiana, C. pulcherrima, C. tergemina and P. pterocarpum. These preliminary results would be a guide in the selection of potential candidates for further pharmacological study and in search of new drug candidate in treating MRSA infections.

\section{Background}

Natural products and secondary metabolites formed by living systems, notably from plant origin, have shown great potential in treating human diseases such as cancer, coronary heart diseases, diabetes and infectious

\footnotetext{
* Correspondence: goh.joo.kheng@sci.monash.edu.my

'School of Science, Monash University Sunway Campus, Bandar Sunway, 46150 Petaling Jaya, Selangor, Malaysia

Full list of author information is available at the end of the article
}

diseases [1]. According to World Health Organisation, $65-80 \%$ of the world populations rely on traditional medicine to treat various diseases [2]. To date, many plants have been claimed to pose beneficial health effects such as antioxidant and antimicrobial properties. With the emergence of multiple strains of antibiotic resistance microorganism, great interest has been generated in search for potential compounds from plants for therapeutic, medicinal, aromatic and aesthetic uses $[2,3]$. 
Phytochemicals are natural and non-nutritive bioactive compounds produced by plants that act as protective agents against external stress and pathogenic attack [4]. Secondary metabolite is crucial for plant defenses (e.g. as an antioxidant or antimicrobial agent) which has enabled plants to survive. Based on their biosynthetic origin, phytochemicals can be divided into several categories: phenolics, alkaloids, steroids, terpenes, saponins, etc. Phytochemicals could also exhibit other bioactivities such as antimutagenic, anticarcinogenic, antioxidant, antimicrobial, and anti-inflammatory properties [5]. These plant-derived phytochemicals with therapeutic properties could be used as single therapeutic agent or as combined formulations in drug development.

Phenolic is one of the major groups of phytochemical that can be found ubiquitously in certain plants. Phenolic compounds are potent antioxidants and free radical scavenger which can act as hydrogen donors, reducing agents, metal chelators and singlet oxygen quenchers [4]. Studies have shown that phenolic compounds such as catechin and quercetin were very efficient in stabilising phospholipid bilayers against peroxidation induced by reactive oxygen species (ROS) [6,7].

In Malaysia, only 5 - 15\% of more than 250000 species of higher plants with therapeutic potential have been studied [8]. Hence, there is a vast potential to reveal plant resources with useful phytochemicals [9].

The bioactivities of nine medicinal plants from Leguminosae family were assessed in this report. The Leguminosae family comprises of 650 genera and more than 18000 species [9]. Some of these plants were reported as medicinal plants, such as B. kockiana, B. purpurea, C. pulcherrima, C. surattensis which have been used traditionally to treat various diseases. Also, these medicinal plants showed various bioactivities such as anti-cancer, anti-inflammatory, antimicrobial and antioxidant properties. For example, Glycyrrhiza uralensis (kan cao) root ethanolic extracts has chemopreventive properties where it was found to induce apoptosis in MCF-7 breast cancer cells [10]; Trigonella foenum-graecum (fenugreek) seed extract has shown to have hypoglycaemic and hypocholesterolemic properties [11]; isoflavonoids isolated from Erythrina variegata significantly inhibit the growth of MRSA [12]; and Vicia faba (broad bean) showed antimicrobial activity against bacteria such as Escherichia coli, Shigella sp., Bacillus subtilis and Staphylococcus aureus [13].

The main aims of this report are to evaluate antioxidant capacity (total phenolic content and free radical scavenging ability), antibacterial activity and to screen for phytochemicals content in flowers and leaves of nine medicinal plants from Leguminosae family, namely Acacia auriculiformis, Bauhinia kockiana, Bauhinia purpurea, Caesalpinia pulcherrima, Calliandra tergemina, Cassia surattensis, Leucaena leucocephala, Peltophorum pterocarpum, and Samanea saman. To the best of our knowledge, this is the first report on antioxidant and antibacterial activities of most flowers and leaves of selected Leguminosae species.

\section{Methods}

\section{Plant materials and preparation of extracts}

Flowers and leaves of plants of interest were collected from Klang Valley in Peninsular Malaysia and were identified by plant taxonomist, Mr. Anthonysamy Savarimuthu. The plant materials were collected on the day when extraction was performed. Voucher specimens (MUM-LEGUM-001 - MUM-LEGUM-009) were deposited in the herbarium of School of Science, Monash University Sunway campus.

\section{Antioxidant activity}

Extraction of flowers and leaves was performed as described by Chew et al. [4]. $1 \mathrm{~g}$ of each sample was frozen with liquid nitrogen and was ground in a mortar. The powdered samples were then extracted with $50 \mathrm{~mL} \mathrm{75 \%} \mathrm{v/v} \mathrm{methanol} \mathrm{and} \mathrm{were} \mathrm{shook} \mathrm{continuously}$ for an hour at room temperature. The extracts were filtered under vacuum and kept at $-20^{\circ} \mathrm{C}$ until further analysis.

\section{Antibacterial activity and phytochemical screening}

$25 \mathrm{~g}$ of fresh plant materials were collected and dried for 1 day using freeze dryer. The dried samples were ground into fine powder using household blender. The powdered materials were extracted with $500 \mathrm{~mL}$ of dichloromethane:methanol (1:1) mixture with continuous stirring for 3 days at room temperature. Then, the extracts were vacuum filtered, and the plant residues were extracted again with $500 \mathrm{~mL}$ of methanol for 1 day at room temperature, and the extracts were filtered again. Both extracts were combined and evaporated under vacuum. The crude extracts were stored in dark at $-20^{\circ} \mathrm{C}$ until further analysis.

\section{Total phenolic content (TPC)}

The total phenolic content (TPC) of extracts was measured using Folin-Ciocalteu method as described previously [4]. $1.5 \mathrm{~mL}$ Folin-Ciocalteu's phenol reagent (Sigma) $(10 \% \mathrm{v} / \mathrm{v})$ and $1.2 \mathrm{~mL} 7.5 \% \mathrm{w} / \mathrm{v} \mathrm{Na}_{2} \mathrm{CO}_{3}$ were added to $0.3 \mathrm{~mL}$ sample extract. The reaction mixture was thoroughly mixed and was incubated in the dark for 30 minutes before the absorbance was measured at $765 \mathrm{~nm}$. TPC was expressed in terms of mg gallic acid equivalents (GAE) per $100 \mathrm{~g}$ fresh material. The calibration equation for gallic acid was $\mathrm{y}=0.0111 x-0.0148$ $\left(\mathrm{R}^{2}=0.9998\right)$, where $x$ is the gallic acid concentration in $\mathrm{mg} / \mathrm{L}$ and $\mathrm{y}$ is the absorbance reading at $765 \mathrm{~nm}$. 


\section{2, 2-diphenyl-1-picrylhydrazyl (DPPH) radical scavenging assay}

DPPH radical scavenging assay was measured according to Chew et al. [4]. $1 \mathrm{~mL}$ of extract with various dilutions was added to $2 \mathrm{~mL}$ of DPPH (Sigma) $(0.15 \mathrm{mM}$ in methanol). The reaction mixtures were incubated for 30 minutes and the absorbance measured at $517 \mathrm{~nm}$. The DPPH scavenging ability was calculated as $\mathrm{IC}_{50}$ and expressed in $\mathrm{mg}$ ascorbic acid (AA) equivalents per $100 \mathrm{~g}$ of fresh material (AEAC) as follows:

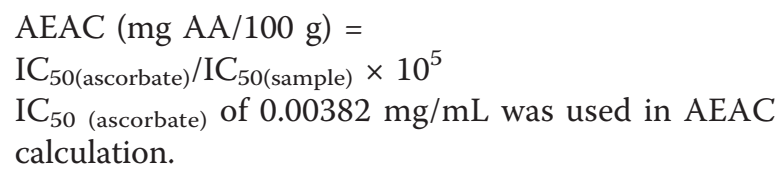

\section{Antibacterial activity \\ Bacteria strains}

Eight species (Gram positive and Gram negative) of bacteria were used. The Gram positive bacteria were Bacillus cereus ATCC 14579, Micrococcus luteus ATCC 4698, methicillin-sensitive Staphylococcus aureus (MSSA) ATCC 25923, and two strains of methicillinresistant S. aureus (MRSA) (ATCC 33591 and clinical strain). The Gram negative bacteria include Escherichia coli ATCC 25922, Klebsiella pneumoniae ATCC 10031, Pseudomonas aeruginosa ATCC 10145, and Enterobacter aerogenes (obtained from Institute for Medical Research Malaysia). All bacteria were cultured on nutrient agar (Oxoid).

\section{Preparation of inoculums}

One single colony of each type of microorganism (from the nutrient agar stock culture) was inoculated with a sterile loop, and was transferred into $10 \mathrm{~mL}$ sterile nutrient broth (Oxoid). The broth cultures were incubated in a shaking incubator at $37^{\circ} \mathrm{C}$ for $16-20$ hours.

\section{Antibacterial susceptibility test: Disc diffusion assay}

The antibacterial assay was performed using disc diffusion (Kirby-Bauer) method [1]. The density of bacteria was standardized using McFarland 0.5 turbidity standard to $1 \times 10^{8}$ coliform units $(\mathrm{cfu}) / \mathrm{mL}$ and was swabbed onto Mueller Hinton Agar (Oxoid) surface. $1 \mathrm{mg}$ of crude extract was dissolved initially in $100 \mu \mathrm{L}$ methanol and loaded onto sterile Whatman No. 1 filter paper discs (6 mm diameter) and the discs were impregnated onto inoculated agar. $10 \mu \mathrm{g}$ of streptomycin or $30 \mu \mathrm{g}$ vancomycin (both from Oxoid) and blank disc without extract were served as positive and negative controls, respectively. The plates were left at $4^{\circ} \mathrm{C}$ for an hour to allow the diffusion of extracts before they were incubated for $16-20$ hours at $37^{\circ} \mathrm{C}$. Antibacterial activity was indicated when clear inhibition zones were noted around the discs. The diameter of the inhibition zones was measured and the results were expressed as mean of three independent experiments. The test was repeated three times.

\section{Determination of minimum inhibitory dosage (MID)}

Minimum inhibitory dosage (MID), minimum dose per disc required to inhibit growth of microorganism was performed on extracts which showed positive activity in the preliminary screening. MID was determined as described by Habsah et al. [14]. Serial dilutions of extracts from 0.01 - $1 \mathrm{mg}$ per disc were loaded onto filter paper discs according to disc diffusion method described above.

\section{Phytochemical analysis}

Phytochemical screening for flavonoids, tannins, saponins and alkaloids was determined as described by Parekh and Chanda [15] and Aiyegoro and Okoh [16], but the amount of extract used was increased for better results visualisation. $1 \mathrm{~g}$ of extract was dissolved in $10 \mathrm{~mL} \mathrm{dH_{2 }} \mathrm{O}$ and was then filtered. $10 \mathrm{mg}$ magnesium turnings were added into $1 \mathrm{~mL}$ of the filtrate, followed by the addition of $0.05 \mathrm{~mL}$ concentrated sulphuric acid. The presence of magenta red observed within three minutes confirmed the presence of flavonoids. The presence of blue-black precipitates resulting from the addition of ferric chloride $(0.01 \mathrm{~g} / \mathrm{mL})$ reagent indicated the presence of tannins. Frothing test was used to determine the presence of saponins, where $2 \mathrm{~mL}$ of the extract was shook vigorously for 4 minutes and the presence of honey-comb froth indicated the existence of saponins. The presence of alkaloids was determined by first dissolving $0.02 \mathrm{~g}$ of extract in $1 \mathrm{~mL}$ methanol and filtered, followed by boiling the extract with $2 \mathrm{~mL}$ of $1 \%$ hydrochloric acid for 5 minutes. 4 - 6 drops of Dragendorff's reagent was then added into the extract, and the formation of orange precipitates indicated the presence of alkaloids. Screening the presence of steroids and terpenoids was performed as described by Kumar et al. [17]. $0.2 \mathrm{~g}$ of extract was dissolved in $10 \mathrm{~mL}$ methanol and filtered. $1 \mathrm{~mL}$ of chloroform and $1 \mathrm{~mL}$ of concentrated sulphuric acid were then added into $1 \mathrm{~mL}$ filtrate by the side of the tube and the presence of yellow with green fluorescence at the sulphuric acid layer indicated the presence of steroids. For the detection of terpenoids, $1 \mathrm{~mL}$ of acetic anhydride and $2 \mathrm{~mL}$ concentrated sulphuric acid were added into $1 \mathrm{~mL}$ filtrate. Presence of reddish brown on interface indicated the presence of terpenoids.

\section{Statistical analysis}

All measurements were carried out in triplicate. Statistical analyses were performed using a one-way analysis of variance ANOVA, and the significant difference between means was determined by Duncan's multiple range test. Differences at $P<0.05$ were considered statistically 
significant. The results were presented as mean values \pm SD (standard deviations).

\section{Results}

\section{TPC and DPPH scavenging activity}

TPC of flowers can be ranked as follows using Folin Ciocalteu assay: B. kockiana $>$ C. surattensis $>$ C. pulcherrima $>A$. auriculiformis $\geq C$. tergemina $>P$. pterocarpum $\geq$ L. leucocephala $>$ S. saman $>B$. purpurea. Slightly different ranking was observed in TPC of the leaves: C. pulcherrima has the highest TPC $(5030 \pm 602 \mathrm{mg}$ GAE/100 g), followed by $P$. pterocarpum (4880 \pm $275 \mathrm{mg} \mathrm{GAE} / 100 \mathrm{~g})$, B. kockiana (4220 $\pm 104 \mathrm{mg}$ GAE/ $100 \mathrm{~g})$, C. tergemina (4200 $\pm 292 \mathrm{mg} \mathrm{GAE} / 100 \mathrm{~g})$, C. surattensis ( $3330 \pm 309 \mathrm{mg} \mathrm{GAE} / 100 \mathrm{~g})$, A. auriculiformis $(2280 \pm 294 \mathrm{mg} \mathrm{GAE} / 100 \mathrm{~g})$, L. leucocephala $(1700 \pm 277 \mathrm{mg} / \mathrm{GAE} / 100 \mathrm{~g})$, S. saman $(1340 \pm 22 \mathrm{mg}$ $\mathrm{GAE} / 100 \mathrm{~g})$ and B. purpurea (1310 $\pm 124 \mathrm{mg} \mathrm{GAE} / 100 \mathrm{~g})$. Statistical analysis showed no significant difference between C. pulcherrima and P. pterocarpum, B. kockiana and $C$. tergemina, A. auriculiformis and L. leucocephala, S. saman and B. purpurea. It was observed that L. leucocephala, S. saman and B. purpurea flowers and leaves were ranked similar, with lowest TPC.
It was found that free radical scavenging activity of the plants was directly proportional to TPC (Figure 1 and Table 1), whereby the higher the TPC of the extract, the stronger the free radical scavenging activity. B. kockiana flower displayed the highest TPC $(8280 \pm 498 \mathrm{mg} \mathrm{GAE} / 100 \mathrm{~g})$ and $\mathrm{AEAC}(14600 \pm$ $2360 \mathrm{mg} \mathrm{AA} / 100 \mathrm{~g}$ ) and strongest $\mathrm{DPPH}$ radical quenching ability, in which $27.0 \pm 5.0 \mu \mathrm{g} / \mathrm{mL}$ of extract could effectively scavenge $50 \%$ of the free DPPH radicals. Whereas, B. purpurea flower consists of much lower TPC and AEAC $(349 \pm 26 \mathrm{mg} \mathrm{GAE} / 100 \mathrm{~g}$ and $235 \pm 35 \mathrm{mg} \mathrm{AA} / 100$ g respectively), and higher concentration of extract was needed to scavenge $50 \%$ of the free radicals $(1690 \pm 280 \mathrm{mg} / \mathrm{mL})$. Strong positive association was observed between TPC and AEAC $\left(R^{2}=0.9747\right)$, while TPC and $I_{50}$ were inversely proportional $\left(R^{2}=0.9753\right)$. This shows that radical scavenging activity is closely associated with the phenolic compounds in these plants.

Statistical analysis showed that TPC and antioxidant activity of flowers and leaves of the same species are significantly different. However, exceptions were seen in A. auriculiformis, C. surattensis, L. leucocephala and S. saman. On the other hand, TPC of both parts of

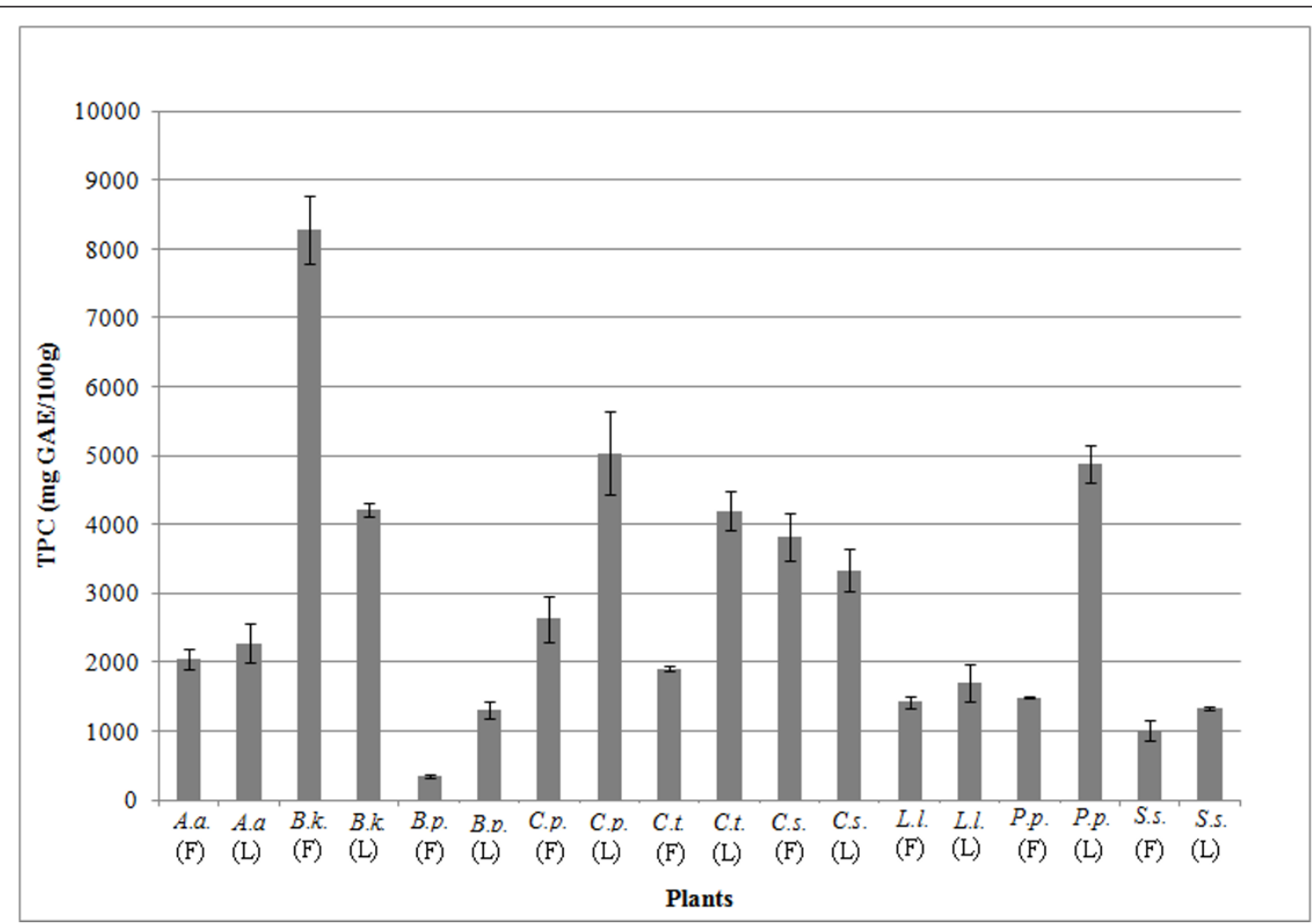

Figure 1 Total phenolic content (TPC) of flowers (F) and leaves (L) of Leguminosae species. Results are expressed as means \pm SD $(n=3)$. A.a. $=$ A. auriculiformis; B.k. = B. kockiana; B.p. = B. purpurea; C.p. $=$ C. pulcherrima; C.t. $=$ C. tergemina; C.s. = C. surattensis; L.I. = L. leucocephala; P.p. $=$ P. pterocarpum; S.s. = S. saman. 
Table 1 Free radical scavenging activity of flowers $(F)$ and leaves (L) of Leguminosae species

\begin{tabular}{|c|c|c|c|}
\hline \multirow[t]{2}{*}{ Plants } & \multirow[t]{2}{*}{ Part } & \multicolumn{2}{|c|}{ Antioxidant activity } \\
\hline & & $I C_{50}(\mu \mathrm{g} / \mathrm{mL})$ & AEAC $(\mathrm{mg} \mathrm{AA} / 100 \mathrm{~g})$ \\
\hline \multirow[t]{2}{*}{ A. auriculiformis } & $\mathrm{F}$ & $152 \pm 13^{a}$ & $2540 \pm 221^{a}$ \\
\hline & L & $161 \pm 30^{\mathrm{a}}$ & $2430 \pm 457^{\mathrm{a}}$ \\
\hline \multirow[t]{2}{*}{ B. kockiana } & $\mathrm{F}$ & $27.0 \pm 5.0^{\mathrm{a}}$ & $14600 \pm 2360^{a}$ \\
\hline & L & $61.0 \pm 10.0^{b}$ & $6410 \pm 985^{b}$ \\
\hline \multirow[t]{2}{*}{ B. purpurea } & $\mathrm{F}$ & $1690 \pm 280^{\mathrm{a}}$ & $235 \pm 35^{\mathrm{a}}$ \\
\hline & $\mathrm{L}$ & $384 \pm 45^{b}$ & $1010 \pm 122^{b}$ \\
\hline \multirow[t]{2}{*}{ C. pulcherrima } & $\mathrm{F}$ & $118 \pm 24^{a}$ & $3350 \pm 618^{a}$ \\
\hline & L & $50.0 \pm 5.0^{b}$ & $7690 \pm 735^{b}$ \\
\hline \multirow[t]{2}{*}{ C. tergemina } & $\mathrm{F}$ & $179 \pm 12^{\mathrm{a}}$ & $2170 \pm 130^{\mathrm{a}}$ \\
\hline & $\mathrm{L}$ & $61.0 \pm 6.0^{b}$ & $6300 \pm 610^{b}$ \\
\hline \multirow[t]{2}{*}{ C. surattensis } & $\mathrm{F}$ & $96.0 \pm 16.0^{a}$ & $4080 \pm 728^{a}$ \\
\hline & L & $94.0 \pm 11.0^{\mathrm{a}}$ & $4130 \pm 463^{a}$ \\
\hline \multirow[t]{2}{*}{ L. leucocephala } & $\mathrm{F}$ & $289 \pm 17^{a}$ & $1340 \pm 78^{a}$ \\
\hline & $L$ & $187 \pm 15^{b}$ & $2070 \pm 156^{b}$ \\
\hline \multirow[t]{2}{*}{ P. pterocarpum } & $\mathrm{F}$ & $189 \pm 10^{\mathrm{a}}$ & $2040 \pm 120^{\mathrm{a}}$ \\
\hline & L & $51.0 \pm 0.0^{b}$ & $7630 \pm 331^{b}$ \\
\hline \multirow[t]{2}{*}{ S. saman } & $\mathrm{F}$ & $343 \pm 43^{a}$ & $1130 \pm 153^{\mathrm{a}}$ \\
\hline & $\mathrm{L}$ & $384 \pm 39^{a}$ & $1000 \pm 97^{a}$ \\
\hline
\end{tabular}

Results are expressed as means $\pm S D(n=3)$. For each column, values followed by the same letter $(a-b)$ are statistically insignificant $(P>0.05)$ as determined using ANOVA, and this does not apply for different plants.

S. saman were shown to be statistically significant but they were not significant in terms of antioxidant activity.

\section{Antibacterial activity and minimum inhibitory dosage (MID) of extracts}

The susceptibility of bacteria towards the plant extracts was assessed. All nine extracts were tested on selected Gram positive and negative bacteria. The screening showed most extracts displayed a broad spectrum of antibacterial activity towards Gram positive but some had selective activity towards the bacteria, i.e. B. purpurea flower exhibited inhibition activity towards antibiotic resistant $S$. aureus (MRSA), but not to the other three Gram positive bacteria (Table 2). No inhibition was observed in Gram negative bacteria at the same dosage for all the plant extracts.

Minimum inhibitory dosage (MID) was evaluated to assess the potency of the extracts in inhibiting the growth of bacteria. The antibacterial activity of B. kockiana flower and $C$. surattensis leaf extracts were strong. Most of the antibacterial activity of the other extracts exhibited medium to weak inhibition activity. It is interesting to observe that $B$. purpurea flower exhibited medium inhibition activity towards MRSA, but inactive against the antibiotic sensitive strain (MSSA) and other Gram positive bacteria. Besides, it was noted that S. saman flower did not exhibit any antibacterial activities towards both Gram positive and negative bacteria tested in this study.

\section{Phytochemical screening}

It has been reported that biological activities in the selected plants were exhibited by different class of phytochemicals [18-24]. Therefore, it is important to screen for phytochemical group in these plants. Phytochemical screening on the 18 extracts showed the presence of different types of chemical constituents. Tannin was detected in most of the extracts (14 extracts), followed by terpenoid (13 extracts), steroid (13 extracts), flavonoid (12 extracts), and saponin (10 extracts). Alkaloid was only present in 4 extracts (Table 3).

\section{Discussion \\ Antioxidant activity}

Plants produce diverse arrays of phytochemicals which are useful in the development of new drugs. These phytochemicals are mostly secondary metabolites constantly synthesized by the plant for defensive purposes [4]. For instance, antioxidants are biologically produced as defensive mechanism to prevent tissues destruction caused by highly reactive chemical species, which are formed from various biochemical reactions.

Excessive free radicals which are produced from various biochemical reactions such as triplet chlorophyll, singlet oxygen and hydroxyl radicals are lethal to plants. One of the major classes of natural antioxidants found in plants that remove such free radicals is polyphenols. Polyphenols are able to neutralize free radicals, scavenge singlet and triplet oxygen, and to break down peroxides. Total polyphenol content (TPC) of plants was evaluated using Folin-Ciocalteu method, which measured the redox properties of polyphenols in extracts [4].

The amount of TPC of selected plants could be categorised into 4 classes: high ( $>5000 \mathrm{mg} \mathrm{GAE} / 100 \mathrm{~g}$ ), medium high (3000 - $5000 \mathrm{mg}$ GAE/100 g), medium low $(1000-3000 \mathrm{mg} \mathrm{GAE} / 100 \mathrm{~g})$ and low $(<1000 \mathrm{mg}$ GAE/100 g). According to Kuete and Efferth [25], free radical scavenging ability was also ranked according to $\mathrm{IC}_{50}$ : high $(<50 \mu \mathrm{g} / \mathrm{mL})$; moderate $(50-100 \mu \mathrm{g} / \mathrm{mL})$ and low $(>50 \mu \mathrm{g} / \mathrm{mL})$. Most of the extracts showed medium level of TPC (medium high: 5 extracts; medium low: 10 extracts). It was noticed that most leaves had higher TPC than the flowers of the same species, i.e. TPC of B. purpurea, C. pulcherrima, C. tergemina, P. pterocarpum and S. saman leaves were significantly higher than their respective flowers (Figure 1). Although TPC of C. surattensis flower was found to be higher than its leaves, they were statistically not significant. From this interesting observation, it could be explained by the 
Table 2 Antibacterial activity of flowers (F) and leaves (L) of Leguminosae species ${ }^{\text {a }}$ evaluated using disc diffusion assay at $1 \mathrm{mg}$ per disc

\begin{tabular}{|c|c|c|c|c|c|c|}
\hline \multirow[b]{3}{*}{ Plants } & \multirow[b]{3}{*}{ Part } & \multicolumn{5}{|c|}{ Bacterial strains } \\
\hline & & \multicolumn{5}{|c|}{ Diameter of zone of inhibition $(\mathrm{mm})$} \\
\hline & & $\begin{array}{l}\text { B. cereus ATCC } \\
14579\end{array}$ & $\begin{array}{c}\text { M. luteus ATCC } \\
4698\end{array}$ & $\begin{array}{l}\text { MSSA ATCC } \\
25923\end{array}$ & $\begin{array}{c}\text { MRSA ATCC } \\
33591\end{array}$ & MRSA (clinical isolate) ${ }^{\mathrm{b}}$ \\
\hline \multirow[t]{2}{*}{ A. auriculiformis } & $\mathrm{F}$ & $10.0 \pm 0.0$ & $11.8 \pm 0.4$ & $11.8 \pm 0.4$ & $15.3 \pm 0.4$ & $13.3 \pm 0.4$ \\
\hline & L & $9.50 \pm 0.7$ & $12.0 \pm 0.0$ & $12.0 \pm 0.0$ & $15.3 \pm 1.1$ & $13.5 \pm 0.7$ \\
\hline \multirow[t]{2}{*}{ B. kockiana } & F & $10.0 \pm 0.0$ & $12.0 \pm 0.0$ & $12.5 \pm 0.7$ & $11.0 \pm 0.0$ & $11.5 \pm 0.7$ \\
\hline & L & $8.00 \pm 0.00$ & $10.0 \pm 0.0$ & $9.50 \pm 0.70$ & $9.00 \pm 0.00$ & $10.0 \pm 0.0$ \\
\hline \multirow[t]{2}{*}{ B. purpurea } & $\mathrm{F}$ & - & - & - & $12.3 \pm 0.4$ & $10.0 \pm 0.0$ \\
\hline & L & $7.00 \pm 0.00$ & $8.30 \pm 0.35$ & $7.00 \pm 0.00$ & $8.00 \pm 0.00$ & - \\
\hline \multirow[t]{2}{*}{ C. pulcherrima } & $\mathrm{F}$ & $7.80 \pm 0.40$ & $10.0 \pm 0.0$ & $10.0 \pm 0.0$ & $9.50 \pm 0.70$ & $9.50 \pm 0.70$ \\
\hline & L & $7.80 \pm 0.40$ & $10.0 \pm 0.0$ & $10.0 \pm 0.0$ & $10.5 \pm 0.7$ & $9.50 \pm 0.70$ \\
\hline \multirow[t]{2}{*}{ C. tergemina } & $\mathrm{F}$ & $7.00 \pm 0.00$ & $7.50 \pm 0.70$ & $8.50 \pm 0.00$ & $9.30 \pm 0.35$ & $8.50 \pm 0.70$ \\
\hline & L & $10.3 \pm 0.4$ & $11.0 \pm 0.0$ & $12.0 \pm 0.0$ & $13.0 \pm 0.0$ & $11.0 \pm 0.0$ \\
\hline \multirow[t]{2}{*}{ C. surattensis } & $\mathrm{F}$ & $7.50 \pm 0.70$ & $10.0 \pm 0.0$ & $10.0 \pm 0.0$ & $11.0 \pm 0.0$ & $10.0 \pm 0.0$ \\
\hline & L & $7.50 \pm 0.70$ & $10.0 \pm 0.0$ & $10.0 \pm 0.0$ & $10.0 \pm 0.0$ & $10.0 \pm 0.0$ \\
\hline \multirow[t]{2}{*}{ L. leucocephala } & $\mathrm{F}$ & - & $9.30 \pm 0.40$ & $8.00 \pm 0.00$ & $11.0 \pm 0.0$ & $8.80 \pm 1.10$ \\
\hline & L & - & $9.00 \pm 0.00$ & $9.30 \pm 0.40$ & $9.30 \pm 0.40$ & $10.0 \pm 0.0$ \\
\hline \multirow[t]{2}{*}{ P. pterocarpum } & $\mathrm{F}$ & $8.00 \pm 0.0$ & $11.3 \pm 0.4$ & $9.80 \pm 0.40$ & $10.8 \pm 0.4$ & $10.3 \pm 0.4$ \\
\hline & L & $9.80 \pm 0.40$ & $12.0 \pm 0.0$ & $11.5 \pm 0.7$ & $11.8 \pm 0.4$ & $10.8 \pm 1.1$ \\
\hline \multirow[t]{2}{*}{ S. saman } & $\mathrm{F}$ & - & - & - & - & - \\
\hline & L & - & $21.3 \pm 0.4$ & $8.50 \pm 0.70$ & $9.00 \pm 0.00$ & $9.30 \pm 0.35$ \\
\hline $\begin{array}{l}\text { Streptomycin }(10 \mu \mathrm{g} / \\
\text { disc) }\end{array}$ & & $24.0 \pm 0.0$ & $27.0 \pm 0.0$ & $14.0 \pm 0.0$ & n.t & n.t \\
\hline Vancomycin (30 $\mu \mathrm{g} /$ disc) & & n.t & n.t & n.t & $21.0 \pm 0.0$ & $21.0 \pm 0.0$ \\
\hline
\end{tabular}

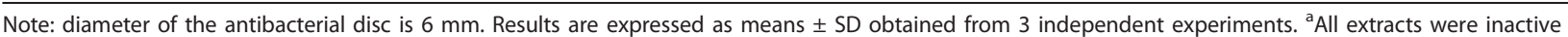
against Gram negative bacteria (Escherichia coli ATCC 25922, Klebsiella pneumoniae ATCC 10031, Pseudomonas aeruginosa ATCC 10145, Enterobacter aerogenes obtained from Institute for Medical Research Malaysia) tested. 'Obtained from Faculty of Medicine and Health Sciences UPM. "-" indicates no inhibition activity. "n.t" represents not tested.

Table 3 Classes of phytochemicals present in the plant extracts

\begin{tabular}{|c|c|c|c|c|c|c|c|}
\hline Plants & Part & Tannin & Terpenoid & Alkaloid & Steroid & Saponin & Flavonoid \\
\hline \multirow[t]{2}{*}{ A. auriculiformis } & $F$ & - & + & + & - & + & - \\
\hline & L & - & + & - & + & + & - \\
\hline \multirow{2}{*}{ B. kockiana } & $\mathrm{F}$ & + & - & - & + & - & + \\
\hline & L & + & - & - & + & - & + \\
\hline \multirow[t]{2}{*}{ B. purpurea } & $\mathrm{F}$ & - & + & + & + & + & + \\
\hline & L & - & + & - & + & + & - \\
\hline \multirow[t]{2}{*}{ C. pulcherrima } & $\mathrm{F}$ & + & + & - & + & - & + \\
\hline & L & + & + & - & + & - & + \\
\hline \multirow[t]{2}{*}{ C. tergemina } & F & + & + & - & + & + & + \\
\hline & L & + & + & - & + & + & + \\
\hline \multirow[t]{2}{*}{ C. surattensis } & F & + & + & - & - & - & + \\
\hline & L & + & - & - & - & - & + \\
\hline \multirow[t]{2}{*}{ L. leucocephala } & $\mathrm{F}$ & + & - & + & - & - & + \\
\hline & L & + & - & - & + & + & + \\
\hline \multirow[t]{2}{*}{ P. pterocarpum } & $F$ & + & + & - & - & + & - \\
\hline & L & + & + & - & + & + & - \\
\hline \multirow[t]{2}{*}{ S. saman } & $F$ & + & + & + & + & + & + \\
\hline & $\mathrm{L}$ & + & + & - & + & - & - \\
\hline
\end{tabular}


differences in antioxidant distribution in the leaves and flowers. Similar observation was discovered in Cassia fistula [26] and Cynara cardunculus [27]. Siddhuraju et al. [26] reported the production of anthraquinones, xanthones, flavonol and proanthocyanidins in leaves would lead to higher antioxidant activity. In addition, del Bano et al. [28] found that some antioxidative compounds were selectively biosynthesized by the leaves but the compounds do not exist in flowers. Our previous study [4] also showed that rutin and chlorogenic acid were present in B. kockiana and C. surattensis leaves but they were absent in their respective flowers. This may be due to higher stress level experienced by the leaves in the process of photosynthesis, where excessive light energy may be absorbed by the leaf tissues. The chlorophylls would also undergo photosensitization process (process of transferring absorbed light energy), which may trigger the production of highly reactive chemical species at cellular level [29]. Therefore, leaf tissues would need to generate highly effective antioxidants and free radical scavengers to aid in quenching and removing the ROS and to minimize the photosensitizationinduced oxidative damage.

Compared to the results showed in most plants, exception was seen in B. kockiana. B. kockiana showed a very unique trend of TPC and free radical quenching ability distribution in the leaves and flowers among the nine selected plants. The TPC and free radical quenching ability were significantly higher in flowers than leaves. Our earlier report [4] showed the presence of high anthocyanins content in B. kockiana flowers. Anthocyanins which act as visual attractant for potential pollinators (i.e. insects) may have contributed to the high phenolic content and strong free radical scavenging power of B. kockiana flower extract. Anthocyanins are the common pigments in coloured flowers that could terminate radical chain reaction, prevent both enzymatic and non-enzymatic lipid peroxidation of cell membranes by binding with fatty radicals [4].

An antioxidative xanthophylls and lutein were found in C. surattensis flower [4]. Lutein protects photoinduced free radical damage in plant tissues in 2 ways: filters off the high energy blue light and scavenges the reactive chemical species [30]. The presence of rutin $(95.7 \mathrm{mg} / 100 \mathrm{~g})$ and chlorogenic acid $(9.13 \mathrm{mg} / 100 \mathrm{~g})$ in extract would exhibit antioxidant activities. Our previous study [4] has shown that rutin was present in C. surattensis flowers and leaves extracts $(13.3 \mathrm{mg}$ rutin equivalent/100 $\mathrm{g}$ and $29.6 \mathrm{mg}$ rutin equivalent/100 g, respectively), assessed using aluminium chloride method. Rutin (95.7 mg/100 g) and chlorogenic acid $(9.13 \mathrm{mg} / 100 \mathrm{~g})$ in extract would exhibit antioxidant activities [4].

\section{Antibacterial activity and phytochemicals screening}

All extracts were not active against Gram negative bacteria. This could be due to the presence of outer membrane as a permeability barrier in Gram negative bacteria. The presence of porin at the outer membrane of Gram negative bacteria restricted the diffusion of many antibiotics and the multidrug efflux pumps at the transmembrane would also pump out the antibacterial agents through the active efflux processes which would hence create a higher intrinsic resistance for Gram negative bacteria [31]. It is interesting to note that this is the first report on the inhibition activity of most plant extracts against MRSA.

As phytochemicals often play an important role in plant defence against prey, microorganism, stress as well as interspecies protections, these plant components have been used as drugs for millennia. Hence, phytochemicals screening serves as the initial step in predicting the types of potential active compounds from plants.

The presences of flavonoids [32], triterpenoid saponins [33] and tannins [34] in A. auriculiformis have been reported. Good DPPH free radical scavenging activity of A. auriculiformis is not only attributed to the presence of tannins, but also leucoanthocyanidins (leucodelphinidins and leucocyanidins) which are present abundantly in the plant. This is because of the hydroxylation at 4' orthoposition of leucoanthocyanidins that could change $\mathrm{DPPH}$ radical to non-radical DPPH-H [35]. Besides, two acylated bisglycoside saponins, acaciaside $\mathrm{A}$ and $\mathrm{B}$ isolated from $A$. auriculiformis, were found to exhibit antibacterial and antifungal activity. Mandal et al. [36] found that mixture of these two saponins are able to inhibit conidial germination of Aspergillus ochraceous and Curvularia lunata at $300 \mu \mathrm{g} / \mathrm{mL}$ while the bactericidal concentration of the mixture against Bacillus megaterium, Salmonella typhimurium and $P$. aeruginosa was at $700 \mu \mathrm{g} / \mathrm{mL}$ or higher. Also, three antifungal flavonoids were found in heartwood of $A$. auriculiformis. Mihara et al. [18] proposed that the antifungal activity of 3,4',7,8-tetrahydroxyflavone and teracacidin were correlated to the antioxidant activities, where these antifungal flavonoids could scavenge the free radicals produced by extracellular fungal enzyme laccase, hence inhibiting the mycelia growth of fungus.

The extract of C. pulcherrima has been reported to inhibit the growth of a broad spectrum of bacteria $[19,37,38]$. The extract has also shown antifungal activity against plant pathogens and yeast $[37,38]$. However, none of the Gram negative bacteria were inhibited by C. pulcherrima extracts in our preliminary screening. Mukherjee and Ray [39] and Ali et al. [19] reported the presence of all five classes of phytochemicals in the leaves while tannins, saponins and alkaloids were 
detected in the aerial parts [15]. In contrary, our findings showed alkaloid and saponin were not detected in this plant. The presence of gallic acid, ellagic acid and flavonoids (i.e. myricetin, catechin, rutin, and quercetin) were found in C. pulcherrima flowers [40,41]. However, our previous report [4] showed the presence of rutin but absence of tannins and other flavonoids. This can be explained by the ecophysiological effect and abiotic growth factors that would possibly be the major determining factors which could modify the expression of phytochemicals in the plant [4]. Terpenoids were found in C. pulcherrima $[20,21,42,43]$. Phytochemical compounds in C. pulcherrima that possessed antimicrobial abilities have been isolated. For instance, Srinivas et al. [22] discovered 5,7-dimethylenedioxyflavanone, isobouducellin and 2'hydroxy-2,3,4',6'-tetramethoxychalcone that possessed moderate to good antimicrobial activity against $S$. aureus, B. subtilis, B. sphaericus, A. niger, $R$. oryzae; 3-oxo-(20S,24S)-epoxydammarane-19,25diacetate from $C$. pulcherrima bark. It has exhibited moderately strong antibacterial activity towards $B$. cereus (MIC $16 \mu \mathrm{g} / \mathrm{mL}$ ) and Shiegella dysenteriae (MIC $32 \mu \mathrm{g} / \mathrm{mL}$ ) [20]; and several cassane-furanoditerpenoids were found to exhibit fairly strong inhibition activity against various bacteria and fungus $[42,43]$.

Positive results were seen in L. leucocephala leaves in alkaloid screening (Table 3). It has been reported that mimosine, an alkaloid was detected in this plant $[23,44]$. Studies found that $5.35 \mathrm{~g}$ of mimosine were present in $100 \mathrm{~g}$ of dry L. leucocephala leaves, $0.53 \mathrm{~g} / 100 \mathrm{~g}$ in nodules, $1.49 \mathrm{~g} / 100 \mathrm{~g}$ in roots [44] and $2.38 \mathrm{~g} / 100 \mathrm{~g}$ in mature seeds [45], but no reports found the presence of mimosine in the flowers, and our studies confirmed the absence of alkaloid in the flowers. Chanwitheesuk et al. [46] reported the presence of tannins, vitamin E, ascorbic acid, carotenes, xanthophylls and phenolics in L. leucocephala and they were known to be antioxidative substances, but may also possessed antibacterial properties.

Duraipandiyan et al. [47] reported that methanolic extract of $P$. pterocarpum flower displayed moderate antimicrobial activity against several bacteria strains. In addition, fairly strong antifungal activity $(>50 \%$ inhibition) of leaves extract against Fusarium sp. [48], Aspergillus sp. [24] and Cladosporium cucumerinum [49] were reported, and this shows that $P$. pterocarpum leaf has antifungal bioactive agents which could be applied as fungicide.

This is the first antioxidant, antibacterial and phytochemical screening study for $S$. saman flowers. The presence of low tannin and flavonoid contents in flower could have been contributed to medium low TPC and free radical scavenging activity (Figure 1 and Table 1). However, it was found that the flower extract showed no antibacterial activity (Table 2), and this showed that the phytochemicals present in the flower may not possess any inhibiting activity against the eight bacteria. Our study found the presence of tannins, terpenoids and steroids in the $S$. saman leaves, and the results were consistent with reported findings [50]. However, the presence of saponins and flavonoids in leaves was in contrary to our findings [50]. Mild to medium inhibition antimicrobial activity of $S$. saman leaves extract against various Gram negative bacteria was reported [50]. Ali et al. [19] discovered that antibacterial activity of methanolic extract of $S$. saman leaves was significantly stronger than non-polar hexane extract and this showed that the antibacterial agents in the leaves were mostly hydrophilic in nature. In addition, it was discovered that alkaloid fractions exhibited fairly strong antibacterial activity (MIC values ranging between $7 \mu \mathrm{g} / \mathrm{mL}$ and $20 \mu \mathrm{g} / \mathrm{mL}$ ) [50]. The antibacterial activity of $S$. saman leaves could also be exhibited by alkaloids detected in the extracts, as alkaloid fractions of S. saman was reported to be able to inhibit growth of various bacteria and it was equally potent as gentamycin [50].

\section{Conclusions}

In conclusion, our findings showed some Leguminosae plants, such as B. kockiana, C. pulcherrima, C. tergemina and $P$. pterocarpum have the potential to be explored further to identify the antioxidative and antibacterial compounds in these plants. The present results will serve as the preliminary findings for selection of potential plant species for further investigation, especially in isolating new bioactive compounds, which have strong antioxidant activity and anti-MRSA ability. Studies on isolating bioactive compounds using bioassay guided approach are in progress.

\section{Acknowledgements}

The authors are thankful to Monash University Sunway Campus for financial support. We are grateful to Mr. Anthonysamy Savarimuthu (formerly of Universiti Putra Malaysia) for identifying the plants, and Dr. Vasantha Kumari Neela from Department of Microbiology, Universiti Putra Malaysia for providing clinical strain of MRSA.

\section{Author details}

'School of Science, Monash University Sunway Campus, Bandar Sunway, 46150 Petaling Jaya, Selangor, Malaysia. ${ }^{2}$ Pharmacotherapeutics Unit, Department of Medicine, Faculty of Medicine and Health Sciences, Universiti Putra Malaysia, 43400 Serdang, Selangor Darul Ehsan, Malaysia. ${ }^{3}$ Laboratory of Natural Products, Institute of Bioscience, Universiti Putra Malaysia, 43400 Serdang, Selangor Darul Ehsan, Malaysia.

\section{Authors' contributions}

YLC, EWLC and PLT performed the experimentation as part of their PhD and Honours studies. YLC and EWLC prepared the manuscript. JKG, YYL and JS supervised the work, evaluated the data and corrected the manuscript for publication. All authors read and approved the final manuscript.

Competing interests

The authors declare that they have no competing interests. 
Received: 5 October 2010 Accepted: 10 February 2011

Published: 10 February 2011

\section{References}

1. Lai HY, Lim YY, Kim KH: Blechnum Orientale Linn - a fern with potential as antioxidant, anticancer and antibacterial agent. BMC Complement Altern Med 2010, 10:15.

2. Gurinder JK, Daljit SA: Antibacterial and phytochemical screening of Anethum graveolens, Foeniculum vulgare and Trachyspermum ammi. BMC Complement Altern Med 2009, 9:30.

3. Newman DJ, Cragg GM: Natural products as sources of new drugs over the last 25 years. J Nat Prod 2007, 70:461-477.

4. Chew YL, Goh JK, Lim YY: Assessment of in vitro antioxidant capacity and polyphenolic composition of selected medicinal herbs from Leguminosae family in Peninsular Malaysia. Food Chem 2009, 119:373-378.

5. Yen GC, Duh PD, Tsai CL: Relationship between antioxidant activity and maturity of peanut hulls. J Agric Food Chem 1993, 41:67-70.

6. Gülçin I, Bursal E, Şehitoğlu MH, Bilsel M, Gören AC: Polyphenol contents and antioxidant activity of lyophilized aqueous extract of propolis from Erzurum, Turkey. Food Chem Tox 2010, 48:2227-2238.

7. Gülçin I: Antioxidant properties of resveratrol: A structure-activity insight. Innovative Food Sci Emerging Tech 2010, 11:210-218.

8. Balandrin MF, Kinghorn AD, Farnsworth NR: Plant-derived natural products in drug discovery and development. An overview. In Human Medicinal Agents from Plants. Am Chem Soc Symposium Series 534. Edited by: AD Kinghorn, MF Balandrin. Washington, DC, Amer Chem Soc; 1993:2-12.

9. National Research Council: Tropical Legumes: Resources for the future: New York: Books for Business; 2002.

10. Jo EH, Kim SH, Cho SD, Hwanf JW, Kim TY, Lee YS, Kang KS Chemopreventive properties of the ethanol extract of chinese licorice (Glycyrrhiza uralensis) root: induction of apoptosis and G1 cell cycle arrest in MCF-7 human breast cancer cells. Cancer Letters 2005, 230:239-247

11. Xue WL, Li XS, Zhang J, Liu YH, Wang ZL, Zhang RJ: Effect of Trigonella foenum-graecum (fenugreek) extract on blood glucose, blood lipid and hemorheological properties in streptozotocin-induced diabetic rats. Asia Pacific J Clinical Nutrit 2007, 16:422-426.

12. Tanaka H, Sato M, Fujiwara S, Hirata M, Etoh H, Takeuchi H: Antibacterial activity of isoflavonoids isolated from Erythrina variegata against methicillin-resistant Staphylococcus aureus. Letters in Applied Microbiology 2002, 35:494-498.

13. Peyvast $G$, Khorsandi Z: Antibacterial activity of the broad bean extracts on resistant bacteria. Pakistan J Biol Sci 2007, 10(3):398-402.

14. Habsah M, Amran M, Mackeen MM, Lajis NH, Kikuzaki H, Nakatani N, Rahman AA, Ali AM: Screening of Zingiberaceae extracts for antimicrobial and antioxidant activities. J Ethnopharm 2000, 72:403-410.

15. Parekh J, Chanda SV: In vitro antimicrobial activity and phytochemical analysis of some Indian medicinal plants. Turkish J Biol 2007, 31:53-58.

16. Aiyegoro $\mathrm{OA}$, Okoh Al: Preliminary pytochemical screening and in vitro antioxidant activities of the aqueous extract of Helichrysum longifolium DC. BMC Complement Altern Med 2010, 10:21.

17. Kumar $A$, llavarasan $R$, Jayachandran $T$, Decaraman $M$, Aravindhan $P$, Padmanabhan N, Krishnan MRV: Phytochemical investigation on a tropical plant, Syzygium cumini from Kattuppalayam, Erode District, Tamil Nadu, South India. Pakistan J Nutrit 2009, 8(1):83-85.

18. Mihara R, Barry KM, Mohammed CL, Mitsunaga T: Comparison of antifungal and antioxidant activities of Acacia mangium and $A$. auriculiformis heartwoord extracts. J Chem Ecol 2005, 31(4):789-804.

19. Ali MS, Azhar I, Amtul Z, Ahmad VU, Usmanghani K: Antimicrobial screening of some Caesalpiniaceae. Fitoterapia 1999, 70:299-304.

20. Nasimul Islam AKM, Abbas Ali M, Sayeed A, Abdus Salam SM, Islam A, Rahman M, Astaq Mohal Khan GRM, Khatun S: An antimicrobial terpenoid from Caesalpinia pulcherrima Swartz:: Its characterization, antimicrobial and cytotoxic activities. Asian J Plant Sci 2003, 2(17-24):1162-1165.

21. Roach JS, McLean S, Reynolds WF, Tinto WF: Cassane ditepenoids of Caesalpinia pulcherrima. J Nat Prod 2003, 66:1378-1381.

22. Srinivas KVNS, Koteswara Rao Y, Mahender I, Das B, Rama Krishna KVS, Hara Kishore K, Murty USN: Flavonoids from Caesalpinia pulcherrima. Phytochem 2003, 63(7):789-793.
23. Wee KL, Wang SS: Effect of post-harvest treatment on the degradation of mimosine in Leucaena leucocephala leaves. J Sci Food Agric 1987, 39:195-201.

24. Satish S, Mohana DC, Ranhavendra MP, Raveesha KA: Antifungal activity of some plant extracts against important seed borne pathogens of Aspergillus sp. J Agric Tech 2007, 3:109-119.

25. Kuete V, Efferth T: Cameeroonian medicinal plants: Pharmacology and derived natural products. Frontiers Pharm 2010, 1(123).

26. Siddhuraju P. Mohan PS, Becker K: Studies on the antioxidant activity of Indian Laburnum (Cassia fistula L.): a preliminary assessment of crude extracts from stem bark, leaves, flowers and fruit pulp. Food Chem 2002, 79:61-67.

27. Falleh H, Ksouri R, Chaieb K, Karray-Bouraoui N, Trabelsi N, Boulaaba M, Abdelly C: Phenolic composition of Cynara cardunculus L. organs, and their biological activities. Comptes Rendus Biologies 2008, 331:372-379.

28. del Bano MJ, Lorente J, Castillo J, Benavente-García O, Marín MP, del Río JA Ortuño A, Ibarra I: Flavonoid distribution during the development of leaves, flowers, stems, and roots of Rosmarinus officinalis. Postulation of a biosynthetic pathway. J Agric Food Chem 2004, 52:4987-4992.

29. Bhattacharya S, Kamat JP, Bandyopadhyay SK, Chattopadhyay S: Comparative inhibitory properties of some Indian medicinal plant extracts against photosensitization-induced lipid damage. Food Chem 2009, 113:975-979

30. Alves-Rodrigues A, Shao A: The science behind lutein. Toxicol Letters 2004, 150:57-83

31. Nikaido H: Antibiotic resistance caused by Gram-negative multidrug efflux pumps. Clinical Infect Diseases 1998, 27(Suppl 1):S32-41.

32. Sahai R, Agarwal SK, Rastogi RP: Auriculoside, a new flavon glycoside from Acacia auriculiformis. Phytochem 1980, 19:1560-1562.

33. Garai S, Mahato SB: Isolation and structure elucidation of three triterpenoid saponins from Acacia auriculiformis. Phytochem 1997 44:137-140.

34. Bernhard-Reversat F: The leaching of Eucalyptus hybrids and Acacia auriculiformis leaf littler: laboratory experiments on early decomposition and ecological implications in congolese tree plantations. Applied Soil Ecol 1999, 12:251-261.

35. Tindale MD, Roux DG: A phytochemical survey of the Australian species of Acacia. Phytochem 1969, 8(9):1713-1727.

36. Mandal P, Sinha Babu SP, Mandal NC: Antimicobial activity of saponins from Acacia auriculiformis. Fitoterapia 2005, 76:462-465.

37. Parekh J, Chanda S: In vitro antifungal activity of methanol extracts of some Indian medicinal plants against pathogenic yeast and moulds. African J Biotech 2008, 7(23):4349-4353.

38. Sudhakar M, Rao CV, Rao PM, Raju DB, Venkateswarlu Y: Antimicrobial activity of Caesalpinia pulcherrima, Euphorbia hirta and Asystasia gangeticum. Fitoterapia 2006, 77:378-380.

39. Mukherjee K, Ray LN: Phytochemical screening of some Indian medicinal plant species part II. Pharm Biol 1986, 24(4):187-205.

40. Duke JA, Bogenschutz-Godwin MJ, duCellier J, Duke PK: Handbook of phytochemical constituents of GRAS herbs and other economic plants. Florida: CRC Pressi, 22001

41. Samee W, Vorarat S: Simultaneous determination of gallic acid, catechin, rutin, ellagic acid and quercetin in flower extracts of Michelia alba, Caesalpinia pulcherrima and Nelumbo nucifera by HPLC. Thai Pharm Health Sci J 2008, 2(2):131-137.

42. Ragasa CY, Hofileña JG, Rideout JA: New furanoid diterpenes from Caesalpinia pulcherrima. J Nat Prod 2002, 65:1107-1110.

43. Promsawan N, Kittakoop P, Boonphong S, Nongkunsarn P: Antitubercular cassane furanoditerpenoids from the roots of Caesalpinia pulcherrima. Planta Med 2003, 69:776-777.

44. Soedarjo M, Borthakur D: Mimosine, a toxin produced by the tree legume Leucaena provides a nodulation competition advantage to mimosinedegrading Rhizobium strains. Soil Biol Biochem 1998, 30(12):1605-1613.

45. Xuan TD, Elzaawely AA, Deba F, Fukuta M, Tawata S: Mimosine in Leucaena as a potent bio-herbicide. Agron Sustain Dev 2006, 26:89-97.

46. Chanwitheesuk A, Teerawutgulrag A, Rakariyatham N: Screening of antioxidant activity and antioxidant compounds of some edible plants of Thailand. Food Sci Tech Res 2001, 7:141-144

47. Duraipandiyan V, Ayyanar M, Ignacimuthu S: Antimicrobial activity of some ethnomedicinal plants used by Paliyar tribe from Tamil Nadu, India. BMC Complement Altern Med 2006, 6:35. 
48. Satish S, Raghavendra MP, Raveesha KA: Antifungal potentiality of some plant extracts against Fusarium sp. Archives of Phytopathol Plant Protect 2009, 42(7):618-625.

49. Cavin A, Dyatmyko W, Hostettmann K: Screening of indonesian plants for antifungal and free radical scavenging activities. Pharm Biol 1999, 37:260-268.

50. Prasad RN, Viswanathan S, Renuka Devi J, Nayak V, Swetha VC, Archana BR, Parathasarathy N, Rajkumar J: Preliminary phytochemical screening and antimicrobial activity of Samanea saman. J Med Plants Res 2008, 2(10):268-270,

\section{Pre-publication history}

The pre-publication history for this paper can be accessed here: http://www.biomedcentral.com/1472-6882/11/12/prepub

doi:10.1186/1472-6882-11-12

Cite this article as: Chew et al: Assessment of phytochemical content, polyphenolic composition, antioxidant and antibacterial activities of Leguminosae medicinal plants in Peninsular Malaysia. BMC

Complementary and Alternative Medicine 2011 11:12.

\section{Submit your next manuscript to BioMed Central} and take full advantage of:

- Convenient online submission

- Thorough peer review

- No space constraints or color figure charges

- Immediate publication on acceptance

- Inclusion in PubMed, CAS, Scopus and Google Scholar

- Research which is freely available for redistribution

Submit your manuscript at www.biomedcentral.com/submit 